\title{
STOCK MARKET REACTIONS ON EXCHANGE RATE VOLATILITY: AN INDIAN EXPERIENCE
}

\author{
Lyn Rose ${ }^{1}$, Nithin Jose ${ }^{2}$ (iD) \\ ${ }^{1}$ Postgraduate Student St. Joseph's College (Autonomous), Devagiri, India \\ ${ }^{2}$ Assistant Professor in Commerce St. Joseph's College (Autonomous), Devagiri, India
}

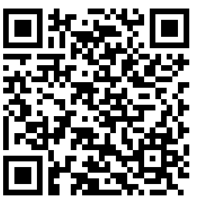

DOI: https://doi.org/10.29121/granthaalayah.v8.i9.2020.1541

Article Type: Research Article

Article Citation: Lyn Rose, and Nithin Jose. (2020). STOCK MARKET REACTIONS ON EXCHANGE RATE VOLATILITY: AN INDIAN EXPERIENCE. International Journal of Research -GRANTHAALAYAH, 8(9), 256-265. https://doi.org/10.29121/granthaa layah.v8.i9.2020.1541

Received Date: 15 September 2020

Accepted Date: 30 September 2020

Keywords:

Exchange Rates

Nifty Return

Stock Market

Causality

VECM

\section{ABSTRACT}

This paper looks at the relationship between Nifty returns and US Dollar - Indian Rupee Exchange Rates. The study looks into the causal relationship between Nifty returns and exchange rate using Granger Causality test. It took daily data covering the period from January, 2009 to June, 2019. In this study, it was found that both variables were nonnormally distributed. With the help of Unit Root Test, it was also verified that Nifty returns as well as Exchange rate, were stationary at the first difference form. Using Granger Causality test it is proved there was a bidirectional relationship between Nifty returns and Exchange rates. From the further investigation it is evident there is a causality running from exchange rate return to stock market return. Finally, employing impulse response function it found that there is a negative relationship among the variables.

\section{INTRODUCTION}

Share price refers to the market value of a firm's single stock on the day it trades. Stock market volatility is the range of price change, a security experiences over a given period of time. Different factors like company performance, corporate image, GDP, exchange rate, interest rate, money supply etc. will influence the stock price. If the price of the stock stays relatively stable, the security has low volatility and vice versa.

Due to globalization the world trade increased, as a result inflow of vast sum of funds between the nations and cross listing of securities also increased. As the world economies are interconnected exchange rates, especially the rates of domestic currencies against US dollar, is of utmost importance to the investor fraternity. Exchange rate is the rate at which one currency is exchanged for another or it may say that, it is the value of one currency for the purpose of conversion to another. Exchange rate volatility that is, unexpected movements in exchange rate have an influence on stock market. Because countries experiencing high volatility can attract only less foreign investment. Moreover, the exchange rate volatility affects the competitiveness of export market and import market, it may have positive or negative effect on the stock market. Here arises the relevance of this research.

(C) 2020 The Author(s). This is an open access article distributed under the terms of the Creative Commons Attribution License, which permits unrestricted use, distribution, and reproduction in any medium, provided the original author and source are credited. 
Talking in the Indian context, a positive move in the exchange rate, that is rupee gaining strength against US Dollar, would have substantial impact over the financials of companies with considerable import bills to be met with their overseas partner. The gain that they could realise from this exchange rate volatility will definitely be reflected by positive movements in their stock values. Likewise, rupee depreciating against dollar would create an affirmative setting for companies with huge export potential, which may result in their stock prices rallying. All the companies that forms the NIFTY 50 is involved in international trade in one way or the other. Inadvertently, they are all sensitive to the exchange rate volatility because such a rate fluctuation will have direct impact on their profitability and financial statements obviously. Thus in an interconnected global financial system, exchange rate is crucial.

Over the years, the researchers have analysed whether there exist significant relationship between share price and exchange rate in India. Most of the study revealed that causality between exchange rate and share price can be identified using the econometric tool Granger-Causality Test. This study endeavour is to identify the effect of exchange rate on stock, by employing Granger-Causality test using the data from the past 10 years (from 2009 to 2019).

\subsection{RESEARCH OBJECTIVE}

An economy's financial position is susceptible to its foreign exchange volatility. Exchange rate volatility has great impact on the financial system of a country especially the stock market. Over the years, a number of researchers have attempted to explain the impact of exchange rate fluctuation on stock market in Indian context as well as global context. But their varying findings have made it impossible to draw a conclusion that can explain the exact relationship between exchange rate and stock market. So, the objective of this study is:

- To identify the effect of exchange rate changes on stock price.

\subsection{RESEARCH HYPOTHESIS}

$\mathrm{H}_{0}$ : There is no causality exist between stock returns and exchange rate

$\mathrm{H}_{1}$ : There is causality exist between stock returns and exchange rate

\section{LITERATURE REVIEW}

Mao and Kao (1990) exporting firm's stock values were seen to be more sensitive to changes in foreign exchange rates. They also found that for an export-dominant country, the currency appreciation reduces the competitiveness of export market and has a negative effect on the domestic stock market. It positively affects the domestic stock market for an import dominant country by lowering import costs.

Alok Kumar Mishra (2004) indicated that stock return, exchange rate return, the demand for money and interest rate are related to each other though no consistent relationship exist between them. The study uses Granger's Causality test and Vector Auto Regression technique.

Daniel Stavarek (2005) considers the causal relationship between stock prices and effective exchange rates in four old EU-member countries and four new EU-member countries and in the USA. He found much stronger causality in countries with developed capital and foreign exchange markets, i.e. old EU-member countries and the USA. And also found a unidirectional causality with a direction running from stock prices to exchange rates.

Charles Adjasi, Simon K Harvey and Daniel Agyapong (2008) analyse the effect of exchange rate volatility on the Ghana stock exchange using EGARCH model. They found a negative relationship between exchange rate volatility and stock market returns, i.e. a depreciation in the local currency leads to an increase in the stock market returns.

K. Kennedy and Farrokh Nourzad (2016) make a study on exchange rate volatility and its effect on stock market volatility using GARCH $(1,1)$ model. They found that when major divers of financial volatility are controlled for, increased exchange rate volatility exerts a positive and statistically significant effect on the volatility of stock returns. 
Kiru Sichoongwe(2016) examines the effect exchange rate volatility on the stock market in Zambia. GARCH $(1,1)$ model was used in establishing the relationship between exchange rate volatility and stock market returns. It was found that there is a negative relationship exist between the variables under study.

Piyali Roy Chowdhury and Anuradha A. (2018) concentrate on the ensuant of exchange rate movements on stock market volatility to forecast the economic scenario in India using correlation model. It found that the stock market have short term fluctuations due to currency value. The study suggest to the Indian stock investors its better to invest for a long run in Indian stock market for a higher return.

\section{DATA AND METHODOLOGY}

The present study is concentrated on the relationship between exchange rate changes and stock price movements. The data collected for the study were Nifty returns and US Dollar - Indian Rupee Exchange Rates. To make the result more precise and reliable, daily level data for a period of 10 years from January 2, 2009 to July 1, 2019 were taken. The data mainly includes: (i) daily closing price of the Nifty index, from which stock returns computed and (ii) US Dollar- Indian Rupee Exchange rates, used to calculate exchange rate returns.

The required data were obtained mainly from secondary sources like Yahoo Finance (www.yahoofinance.com) and Investing.com (www.investing.com). Both the variables daily returns and exchange rated have been matched by calendar dates.

For the purpose of study, the daily stock returns were calculated by considering the natural logarithm of the daily closing prices of Nifty index, i.e. $r=\ln P(t) / P(t-1)$, where $P(t)$ is closing price of the $t^{\text {th }}$ day. In the same way natural logarithm of the exchange rate returns have been also calculated, i.e. $E=\ln E(t) / E(t-1)$. The values so computed were used for studying the relationship between stock returns and exchange rates.

After the extensive literature review, hypotheses were formulated and in order to test those hypotheses various statistical tools/methods used. From the result obtained the inferences or conclusions about the behaviour of two variables under the study was made. The various tests applied for testing the hypotheses include - JB test, Unit root test and Granger Causality test, VECM and impulse response test which were conducted with the assistance of Eviews software (version10.0).

\subsection{NORMALITY TEST}

The Jarque - Bera Test is used to test whether the two variables namely stock returns and exchange rates individually follow the normal probability distribution. It checks that whether the data have the skewness and kurtosis matching a normal distribution.

$$
\mathrm{JB}=\mathrm{n}\left[\mathrm{S}^{2} / 6+(\mathrm{K}-3)^{2} / 24\right]
$$

Where $\mathrm{n}$ = sample size, $\mathrm{S}=$ skewness coefficient, and $\mathrm{K}=$ Kurtosis coefficient. If the variables follow a normal distribution then the value of the skewness and kurtosis will be 0 and 3 respectively. Skewness coefficient, other than 0 indicates the asymmetry in the distribution and Kurtosis value other than 3 denotes leptokurtic or platykurtic.

\subsection{UNIT ROOT TEST (STATIONARITY TEST)}

A unit root test has been used to test whether a series is stationary or not. The available data series is said to be stationary if its mean and variance are constant or fixed over time and the value of covariance between two time periods depends only on the distance or lag between the two time periods and not on the actual time at which the covariance is computed [Gujrati (2003)]. Augmented Dickey Fuller (ADF) was used for testing stationarity condition of stock returns and exchange rates [Dickey and Fuller $(1979,1981)$, Gujrati (2003), Enders (1995)].

The Augmented Dickey-Fuller test specification used here is as given below:

$$
\Delta \mathrm{Y}_{\mathrm{t}}=\mathrm{b}_{0}+\beta \mathrm{Y}_{\mathrm{t}-1}+\mu 1 \Delta \mathrm{Y}_{\mathrm{t}-1}+\mu_{2} \Delta \mathrm{Y}_{\mathrm{t}-2}+\ldots .+\mu_{\mathrm{p}} \Delta \mathrm{Y}_{\mathrm{t}-\mathrm{p}}+\mathrm{e}_{\mathrm{t}}
$$


$\mathrm{Y}_{\mathrm{t}}$ represents time series to be tested, $\mathrm{b}_{0}$ is the intercept term, $\beta$ is the coefficient of interest in the unit root test, $\mu_{\mathrm{i}}$ is the parameter of the augmented lagged first difference of $Y_{\mathrm{t}}$ to represent the $\mathrm{p}^{\text {th }}$ order autoregressive process, and $e_{t}$ is the white noise error term.

\subsection{GRANGER CAUSALITY TEST}

As per the concept of Granger's Causality Test $(1969,1988)$, a time series $X_{t}$ is said to be Granger-cause another time series $Y_{t}$, if we can foretell the series $Y_{t}$ exactly by using past data of $X_{t}$-series. When it is possible to do so, i.e. the values of $X_{t}$ series were providing statistically significant information about future values of $Y_{t}$ series, then we can remark that $X_{t}$ Granger cause $Y_{t .}$ It simply means, $X_{t}$ values are sufficient to predict $Y_{t}$ values. In order to apply Granger causality test it is necessary to verify the stationarity of the variables in the pair as well as the suitable lag length for each pair of variables. For finding appropriate lag length, we used the vector auto regression (VAR) lag order selection method available in Eviews. This technique uses six criteria namely Log likelihood value (log L), sequential modified likelihood ratio (LR) test statistic, final prediction error (FPE), Akaike information criterion (AIC), Schwarz information criterion (SC) and Hannan-Quin information criterion (HQ) for selecting the best lag length. Among the six criteria, I select the optimal lag length by considering AIC, i.e. the lag length corresponding to AIC associated with a $*$ mark.

The Granger Causality test is performed as given below:

$\Delta$ SRTNt $=\alpha 1+\beta 11 \Delta$ ERTNt-1 $+\beta 12 \Delta$ ERTNt-2 $+\ldots+\beta 1 \mathrm{n} \Delta$ ERTNt-n $+\gamma 11 \Delta$ SRTNt-1 $+\gamma 12 \Delta$ SRTNt-2+..+ $\gamma 1 \mathrm{n} \Delta$ SRTNt-n $+\varepsilon 1 . \mathrm{t}$

$\Delta$ ERTNt $=\alpha 2+\beta 21 \Delta$ SRTNt-1 $+\beta 22 \Delta$ SRTNt-2 $+\ldots+\beta 2 n \Delta$ SRTNt-n $+\gamma 21 \Delta$ ERTNt-1 $+\gamma 22 \Delta$ ERTNt- $2+\ldots+$ $\gamma 2 \mathrm{n} \Delta$ ERTNt-n $+\varepsilon 2 . \mathrm{t}$

Where, $\triangle$ SRTNt is the first difference at time ' $\mathrm{t}$ ' of stock market return, $\Delta$ ERTNtis the first difference at time ' $\mathrm{t}$ ' of exchange rate return. ' $\alpha$ ' is the constant, ' $n$ ' is a positive integer, $\beta \mathrm{j}$ and $\gamma$ jare parameters and $\varepsilon$ tis an error term.

\subsection{VECTOR ERROR CORRECTION MODEL}

The VECM is a restricted vector autoregression (VAR) model designed for use with variables that are cointegrated. The foremost advantage of VECM is that it has nice interpretation with long term and short term equations. Generally in a situation where there is cointegration, VECM is required. If the variables are stationary, then one can claim that cointegration exist between the variables Xt and Yt. According to Engle and Granger (1987), The existence of the cointegration implies a causality among the set of variables. If cointegration exist between Xt and Yt, an error correction term is required in testing Granger causality as shown below:

$$
\begin{array}{r}
\Delta \mathrm{Xt}=\alpha 0+\delta 1(\mathrm{Xt}-1-\gamma \mathrm{Yt}-1)+\sum \alpha 1 \mathrm{i} \Delta \mathrm{Xt}-\mathrm{i}+\sum \alpha 2 \mathrm{i} \Delta \mathrm{Yt}-\mathrm{i}+\varepsilon 1 \mathrm{t} \\
\Delta \mathrm{Yt}=\beta 0+\delta 2(\mathrm{Xt}-1-\gamma \mathrm{Yt}-1)+\sum \beta 1 \mathrm{i} \Delta \mathrm{Xt}-\mathrm{i}+\sum \beta 2 \mathrm{i} \Delta \mathrm{Yt}-\mathrm{i}+\varepsilon 2 \mathrm{t}
\end{array}
$$

Where, $\delta 1$ and $\delta 2$ denote speed of adjustment.

\subsection{IMPULSE RESPONSE}

The impulse response function, as an econometric technique, has been employed to investigate the short run impact caused by the vector auto regression model when it received some impulses. The impulse response function describes the response to the error by the endogenous variables. In other words, it identify the responsiveness of the dependent variables (endogenousvariables) in theVAR when shock is put to the error term such as U1 and U2 at the equation given below. It depicts the current and future responses of endogenous variables to one standard deviation on the disturbing term. The following VAR system models have been framed to capture the responsiveness of SRTN (stock market return) and ERTN (exchange rate return) when the shock is given to the error terms.

$$
\begin{aligned}
& \text { SRTN }=\mathrm{b} 1+\beta 2 * \text { ERTNt-i }+\beta 3 * \text { SRTNt-i+U1 } \\
& \text { ERTN }=\mathrm{b} 4+\beta 5^{*} \text { SRTNt-i }+\beta 6^{*} \text { ERTNt-i }+\mathrm{U} 2
\end{aligned}
$$


Where $b 1$ and $b 4$ are the intercepts, $\beta_{2}, \beta_{3}, \beta_{5}$ and $\beta_{6}$ are the beta coefficients; ' $t$-i' is the lag period ( $i=1$ to $n$ ); $U_{1}$ and $\mathrm{U}_{2}$ are error terms.

\section{EMPIRICAL ANALYSIS}

For the purpose of study, analysis of data was carried out in five stages.

First, normality test was employed on the both the series to identify the nature of their distribution. For that, Jarque-Bera statistics were computed using Eviews, which is shown in Table 1.1. For a normal distribution the value of skewness and kurtosis will be 0 and 3 respectively. In our study, from the obtained statistics, it is clear that both the variables namely Nifty returns and exchange rate returns are non-normally distributed. The skewness values for Nifty returns and exchange rate returns are .968974 and .082092 respectively and kurtosis values are 21.01739 and 8.942194 respectively.

Table 1.1: Descriptive statistics

\begin{tabular}{|c|c|c|}
\hline & ERTN & SRTN \\
\hline Mean & 0.000140 & 0.000530 \\
\hline Median & 0.000000 & 0.000513 \\
\hline Maximum & 0.036936 & 0.163343 \\
\hline Minimum & -0.035504 & -0.063802 \\
\hline Std. Dev. & 0.004919 & 0.011388 \\
\hline Skewness & 0.082092 & 0.968974 \\
\hline Kurtosis & 8.942194 & 21.01739 \\
\hline Jarque-Bera & 3775.129 & 35082.16 \\
\hline Probability & 0.000000 & 0.000000 \\
\hline Sum & 0.358741 & 1.359568 \\
\hline Sum Sq. Dev. & 0.062024 & 0.332398 \\
\hline Observations & 2564 & 2564 \\
\hline
\end{tabular}

Second, unit root test was conducted to check whether stationarity exist in the series. A time series is said to be stationary, if the mean and variance of the series are constant or fixed over time. Simplest way to verify the stationarity is to plot time series graph as shown in Fig 2.1 and Fig 2.2 and observe the fluctuations.

Stock Market Return

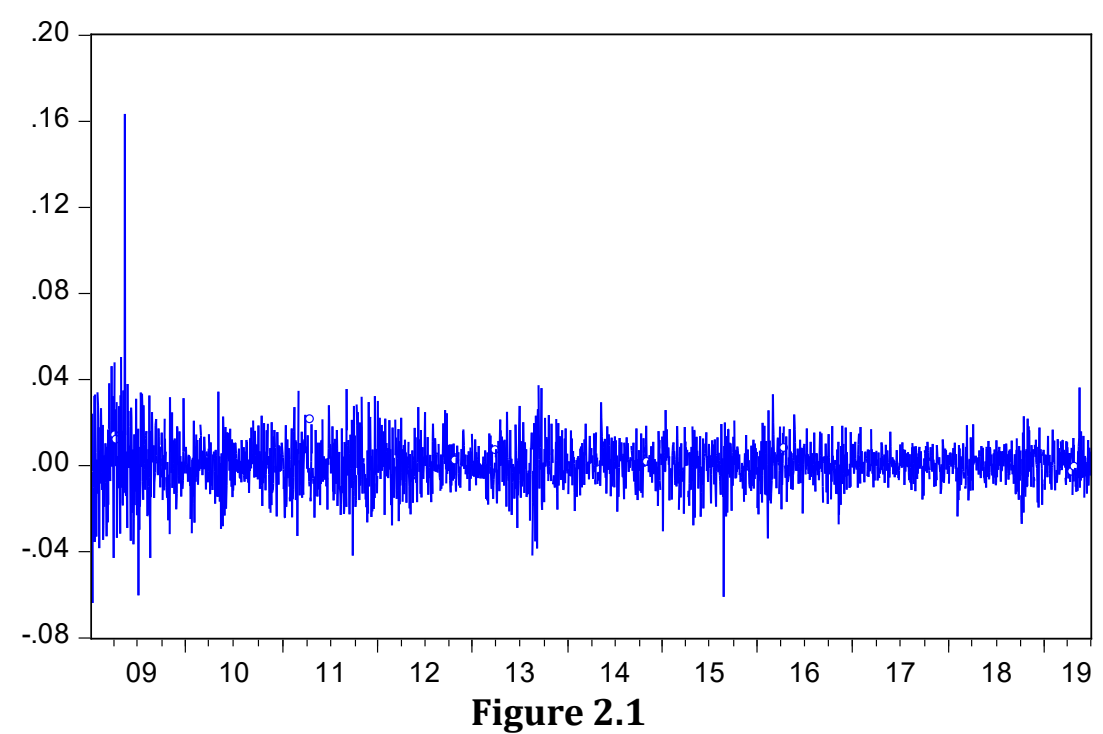




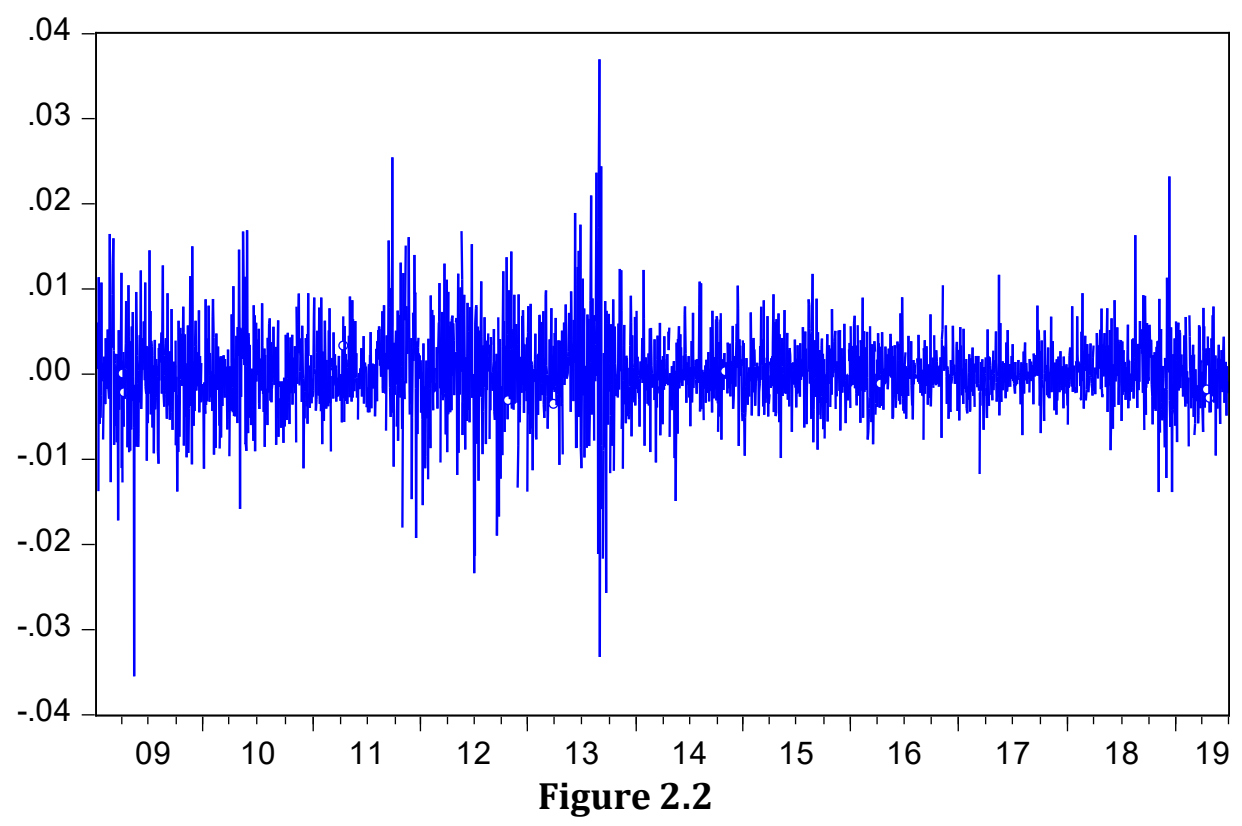

In addition to visual inspection, a formal econometric test namely ADF test can also be execute to verify the stationarity of both series. The results of ADF test are shown in Table 1.2.

\section{Table 1.2 Result of Augmented Dickey Fuller Test}

Table 1.2.1: ADF on Nifty returns series

\begin{tabular}{|c|c|c|c|}
\hline \multicolumn{4}{|c|}{ Null Hypothesis: D(LOG_SMR_) has a unit root } \\
\hline \multicolumn{2}{|c|}{ Exogenous: Constant } & & \\
\hline \multicolumn{4}{|c|}{ Lag Length: 0 (Automatic - based on SIC, maxlag=27) } \\
\hline & & t-Statistic & Prob.* \\
\hline \multicolumn{2}{|c|}{ Augmented Dickey-Fuller test statistic } & -47.84750 & 0.0001 \\
\hline \multirow[t]{3}{*}{ Test critical values: } & $1 \%$ level & -3.432708 & \\
\hline & $5 \%$ level & -2.862468 & \\
\hline & $10 \%$ level & -2.567309 & \\
\hline
\end{tabular}

Table 1.2.2: ADF on exchange rate series

\begin{tabular}{|c|c|c|c|}
\hline \multicolumn{4}{|c|}{ Null Hypothesis: D(LOG_ER_) has a unit root } \\
\hline \multicolumn{2}{|c|}{ Exogenous: Constant } & & \\
\hline \multicolumn{4}{|c|}{ Lag Length: 1 (Automatic - based on SIC, maxlag=27) } \\
\hline & & t-Statistic & Prob.* \\
\hline \multicolumn{2}{|c|}{ Augmented Dickey-Fuller test statistic } & -38.03328 & 0.0000 \\
\hline \multirow[t]{3}{*}{ Test critical values: } & 1\% level & -3.432709 & \\
\hline & $5 \%$ level & -2.862468 & \\
\hline & $10 \%$ level & -2.567309 & \\
\hline & 6) & d p-values. & \\
\hline
\end{tabular}

The critical values for rejection of hypothesis of existence of unit root is at 5\% significance level i.e. -2.862468 . While taking the obtained ADF statistics for the two variables namely Nifty returns and exchange rate returns, it is clear that the obtained statistics are -47.84750 and -38.03328 respectively. Since the obtained statistics fall behind the critical value or the probability value is equal to 0.00 , the hypothesis of unit root for both the series can be 
rejected. Finally, based on ADF test, it can be concluded that both Nifty returns and exchange rate returns are said to be stationary at first difference form.

Third, Granger causality test was made with the objective of identifying the causality of relationship between the variables under study. Results are shown in Table 1.3. From the obtained statistics we can conclude that the null hypothesis- "Exchange rates do not Granger cause stock returns" should be rejected, since the probability value obtained is 0.00 . At the same time we also reject the null hypothesis- "Stock returns do not Granger cause the exchange rates", since the probability value is 0.01 .

Table 1.3: Result of Granger Causality Test

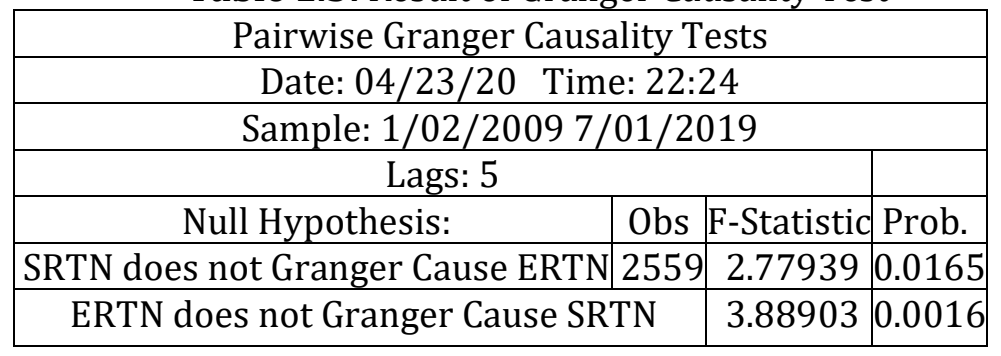

Finally, from the results obtained with help of Granger causality test it is clear that stock returns direct the exchange rates and vice versa, i.e. there exist a bidirectional causality only.

Fourth, VECM is a restricted VAR which is used with the cointegrated time series data to distinguish the long run and short run relationship between the variables. The result of VECM is shown in Table 1.4. C(1) is the coefficient of the cointegrating model or equation [(SRTN(-1) +1.32702901033*ERTN(-1) - 0.000746982561707)]. C(1) shows the speed of adjustment towards long run equilibrium, but it must be significant and the sign must be negative. From the obtained result, the sign of coefficient is negative (-1.165847) and it is significant, because the probability values is $0 \%(0.0000)$ which is less than level of significance. So, there is a long run causality from the independent variable called exchange rate return.

$\mathrm{C}(7), \mathrm{C}(8), \mathrm{C}(9), \mathrm{C}(10)$ and $\mathrm{C}(11)$ are the short run coefficients of the independent variable exchange rate return. The $\mathrm{H} 0$ is $\mathrm{C}(7)=\mathrm{C}(8)=\mathrm{C}(9)=\mathrm{C}(10)=\mathrm{C}(11)=0$, meaning that there is no short run causality running from exchange rate return to stock market return. From the obtained result, the probability value is $0 \%(0.0000)$ which is less than the level of significance (5\%). So we can reject the null hypothesis. Therefore, there is a short run causality from exchange rate return to stock market return. The result of Wald statistics shown in Table 1.5.

Table 1.4: Result of Vector Error Correction Model

\begin{tabular}{|c|c|c|c|c|}
\hline \multicolumn{5}{|c|}{ Sample (adjusted): 1/14/2009 7/01/2019 } \\
\hline \multicolumn{5}{|c|}{ Included observations: 2558 after adjustments } \\
\hline \multicolumn{5}{|c|}{$\mathrm{D}(\mathrm{SRTN})=\mathrm{C}(1) *\left(\right.$ SRTN $(-1)+1.32702901033^{*}$ ERTN $(-1)-$} \\
\hline \multicolumn{5}{|c|}{$0.000746982561707)+\mathrm{C}(2) * \mathrm{D}(\operatorname{SRTN}(-1))+\mathrm{C}(3) * \mathrm{D}(\mathrm{SRTN}(-2))+$} \\
\hline \multicolumn{5}{|c|}{$\mathrm{C}(4) * \mathrm{D}(\operatorname{SRTN}(-3))+\mathrm{C}(5) * \mathrm{D}(\operatorname{SRTN}(-4))+\mathrm{C}(6) * \mathrm{D}(\operatorname{SRTN}(-5))+\mathrm{C}(7)$} \\
\hline \multicolumn{5}{|c|}{${ }^{*} \mathrm{D}($ ERTN $(-1))+\mathrm{C}(8) * \mathrm{D}($ ERTN $(-2))+\mathrm{C}(9) * \mathrm{D}(\operatorname{ERTN}(-3))+\mathrm{C}(10)$} \\
\hline \multicolumn{5}{|c|}{$*$ D(ERTN $(-4))+C(11) *$ D $(\operatorname{ERTN}(-5))+C(12)$} \\
\hline & Coefficient & Std. Error & t-Statistic & Prob. \\
\hline$C(1)$ & -1.165847 & 0.059122 & -19.71941 & 0.0000 \\
\hline$C(2)$ & 0.18 & 0.052941 & 3.479441 & 05 \\
\hline $\mathrm{C}(3)$ & 0.139376 & 0.046567 & 2.993021 & 0.0028 \\
\hline $\mathrm{C}(4)$ & 2988 & 0.039606 & 2.852775 & 0.0044 \\
\hline$C(5)$ & 0.094033 & 0.031731 & 2.963466 & 0.0031 \\
\hline$C(6)$ & 0.030679 & 0.022602 & 1.357366 & 0.1748 \\
\hline$C(7)$ & 1.209211 & 0.081769 & 14.78818 & 0.0000 \\
\hline $\mathrm{C}(8)$ & 0.928085 & 0.079847 & 11.62322 & 0.0000 \\
\hline$C(9)$ & 0.696256 & 0.074931 & 9.291996 & 0.0000 \\
\hline
\end{tabular}


Lyn Rose, and Nithin Jose

\begin{tabular}{|l|l|l|l|l|}
\hline $\mathrm{C}(10)$ & 0.488853 & 0.064981 & 7.523002 & 0.0000 \\
\hline $\mathrm{C}(11)$ & 0.158838 & 0.049393 & 3.215807 & 0.0013 \\
\hline $\mathrm{C}(12)$ & $5.13 \mathrm{E}-06$ & 0.000227 & 0.022628 & 0.9819 \\
\hline
\end{tabular}

Table 1.5: Result of Wald Statistics

\begin{tabular}{|c|c|c|c|}
\hline \multicolumn{2}{|c|}{ Wald Test: } & & \\
\hline \multicolumn{3}{|c|}{ Equation: Untitled } & \\
\hline Test Statistic & Value & $\mathrm{df}$ & Probability \\
\hline F-statistic & 45.12047 & $(5,2546)$ & 0.0000 \\
\hline Chi-square & 225.6023 & 5 & 0.0000 \\
\hline \multicolumn{4}{|c|}{ Null Hypothesis: $C(7)=C(8)=C(9)=C(10)=C(11)=0$} \\
\hline \multicolumn{4}{|c|}{ Null Hypothesis Summary: } \\
\hline \multicolumn{2}{|c|}{ Normalized Restriction $(=0)$} & Value & Std. Err. \\
\hline \multicolumn{2}{|c|}{$\mathrm{C}(7)$} & 1.209211 & 0.081769 \\
\hline \multicolumn{2}{|c|}{$\mathrm{C}(8)$} & 0.928085 & 0.079847 \\
\hline \multicolumn{2}{|c|}{$\mathrm{C}(9)$} & 0.696256 & 0.074931 \\
\hline \multicolumn{2}{|c|}{$C(10)$} & 0.488853 & 0.064981 \\
\hline \multicolumn{2}{|c|}{$\mathrm{C}(11)$} & 0.158838 & 0.049393 \\
\hline
\end{tabular}

Finally, the impulse response function is employed to find the pattern of how a shock in exchange rate return affect stock market return and vice versa. The graph of impulse response function helps to trace out how typical shocks will affect a variable through time. Figure 5. 1 shows when one SD shock is given to exchange rate return(ERTN) how the stock market return(SRTN) is reacting. When the exchange rate return has a positive shock then stock market return becomes negative. From the figure it is possible to observe that exchange rate return has an immediate negative effect on stock market return. The shock effect troughs during the sixth month and remains negative throughout all ten months. Figure also shows when one SD shock is given to stock market return(SRTN) how the exchange rate return(ERTN) is reacting. When the stock market return has a positive shock then exchange rate return becomes negative. It could be identified that during the first month there is an immense increase in the value, which means the negativity of the value decreases and continues to be same for the further period.

Response to Cholesky One S.D. (d.f. adjusted) Innovations
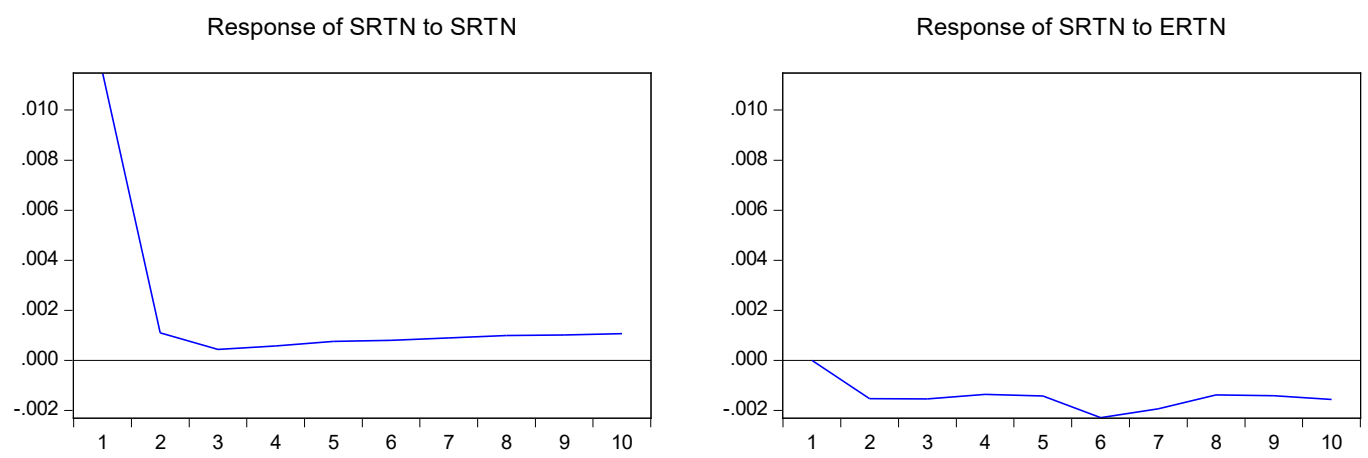

Response of ERTN to SRTN

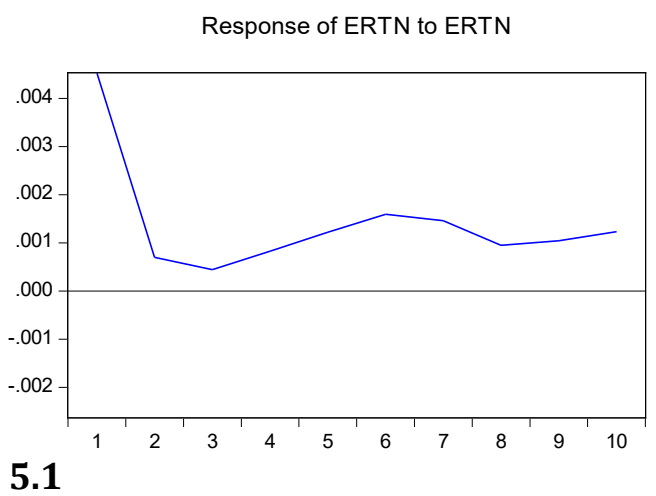

Figure 5.1 


\section{CONCLUSION}

The study is conducted to analyse the effect of exchange rate volatility on stock market volatility. To check the normality of available data the series were converted into log forms. With help of Jarque-Bera test it found that both the series namely Nifty returns and exchange rates are non-normally distributed. The stationarity of series is also conducted by the application of ADF test. From the result it affirmed that both series are stationary at first difference forms. The Granger causality test was applied to the two variables under study and found that there is a causality running from stock returns to exchange rates as well as exchange rates to stock return. This means a bidirectional causality exist between exchange rate and share price. So each variable has an influence on the other. Also it is found that exchange rate return have significant impact on Nifty return in the long run as well as in the short run. From the impulse response function, it can be inferred that there is a negative relationship among the variables. In conclusion it can say that, the financial analysts, economists and the investors can use the past exchange rate data to forecast share price for making better policies and for creating good portfolios.

\section{SOURCES OF FUNDING}

This research received no specific grant from any funding agency in the public, commercial, or not-for-profit sectors.

\section{CONFLICT OF INTEREST}

The author have declared that no competing interests exist.

\section{ACKNOWLEDGMENT}

None.

\section{REFERENCES}

[1] Adaramola Anthony Olugbenga (2012). "Exchange Rate Volatility and Stock Market Behaviour: The Nigerian Experience.” European Journal of Business and Management, Vol-4, No-5, pp. 31-39.

[2] Alok Kumar Mishra (2004). "Stock Market and Foreign Exchange Market in India: Are they Related." South Asia Economic Journal, Vol-5, pp. 209-232.

[3] Charles Adjasi, Simon K. Harvey \& Daniel Agyapong (2008). "Effect of Exchange Rate Volatility on the Ghana Stock Exchange.” African Journal of Accounting, Economics, Finance and Banking Research, Vol-3, pp. 28-47.

[4] Christopher K Ma \& G Wenchi Kao (1990). “On Exchange Rate Changes and Stock Price Reactions.” Journal of Business Finance \& Accounting, Vol-17(3), pp. 441-449.

[5] Clive W.J. Granger, Bwo-Nung Huang \& Chin-Wei Yang (2000). "A Bivariate Causality between Stock Prices and Exchange Rates: Evidence from Recent Asian Flu." The Quarterly Review of Economics and Finance, Vol.40, pp. 337- 354.

[6] Daniel Stavarek (2005). "Stock Prices and Exchange Rates in the EU and the USA: Evidence of their Mutual Interactions." Czech Journal of Economics and Finance, Vol. 55, No. 3-4, pp. 141-161.

[7] Dharmendra Singh (2010). "Causal Relationship Between Macro-Economic Variables and Stock Market: A Case Study for India.” Pakistan Journal of Social Sciences, Vol-30, No-2, pp. 263-274.

[8] Gaurav Agarwal, Aniruddh Kumar Srivastav \& Ankita Srivastava (2010). "A Study of Exchange Rate Movement and Stock Market Volatility.” International Journal of Business and Management, Vol-5, pp. 62-73.

[9] Guneratne B Wickremasinghe (2012). "Stock Prices and Exchange Rates in Sri Lanka: Some Empirical Evidence." Investment Management and Financial Innovations, Vol-9, No-4, pp. 7-13.

[10] KiruSichoongwe (2016). "Effects of Exchange Rate Volatility on the Stock Market: The Zambian Experience." Journal of Economics and Sustainable Development, Vol-7, No-4. pp. 114-119.

[11] K. Kennedy \& Farrokh Nourzad (2016). "Exchange Rate Volatility and its Effect on Stock Market Volatility." International Journal of Human Capital in Urban Management, Vol-1, pp. 37-46. 
[12] Mansor H Ibrahim (2000). "Cointegration and Granger Causality Tests of Stock Price and Exchange Rate Interactions in Malaysia." ASEAN Economic Bulletin. Vol-17, No-1, pp. 36-47.

[13] Mazila Md-Yusaf, Hamisah Abd Rahman (2012). "The Granger Causality Effect Between the Stock Market and Exchange Rate Volatility in the ASEAN 5 Countries.” in Proc.of the IEEE Symposium on Business, Engineering and Industrial Applications (ISBEIA), pp. 754-759.

[14] Mazila Md-Yusaf, Hamisah Abd Rahman (2012). "Causality Effect between Equity Market and Exchange Rate Volatility in Malaysia." International Proceedings of Economics Development and Research (IPEDR), Vol-55, No-22, pp. 109-114.

[15] Muhammad Lawal, Victor Ushahembaljirshar (2013). "Empirical Analysis of Exchange Rate Volatility and Nigeria Stock Market Performance." International Journal of Scientific and Research, Vol-4, No-4, pp. 15921600.

[16] Piyali Roy Chowdhury, Anuradha A. (2018). "Impact of Exchange Rate Fluctuation on Stock Market Volatility - A Study to Predict the Economic Scenario in India.” International Journal of Pure and Applied Mathematics, Vol-118, No-18, pp. 4309-4316.

[17] Richard A. Ajayi, Joseph Friedman \&Seyed M. Mehdian (1998). "On the Relationship Between Stock Returns and Exchange Rates: Tests of Granger Causality." Global Finance Journal, Vol-9(2), pp. 241-251.

[18] Samveg Patel (2012). "The effect of Macroeconomic Determinants on the Performance of the Indian Stock Market." NMIMS Management Review, Vol- XXII, pp. 117-127.

[19] Sheng-Yung Yang, Shuh-ChyiDoong (2004). "Price and Volatility Spillovers between Stock Prices and Exchange Rates: Empirical Evidence from the G-7 Countries." International Journal of Business and Economics, Vol-3, No-2, pp.139-153.

[20] TantatapeBrahmasrene, Jui-Chi Huang \& Yaya Sissoko (2014). “Crude Oil Prices and Exchange Rates: Causality, Variance Decomposition and Impulse Response.” Energy Economics, Vol-44, pp. 407-412.

[21] Yutaka Kurihara (2006). "The Relationship between Exchange Rate and Stock Prices during the Quantitative Easing Policy in Japan." International Journal of Business, Vol-11(4), pp. 375-386. 